\title{
A Hexokinase Associated with Catabolite Repression in Pachysolen tannophilus
}

\author{
By D. N. WEDLOCK AND R. J. THORNTON* \\ Microbiology and Genetics Department, Massey University, Palmerston North, New Zealand
}

(Received 24 June 1988; revised 24 January 1989; accepted 28 March 1989)

\begin{abstract}
A hexokinase (ATP : D-hexose 6-phosphotransferase; EC 2.7.1.1) associated with catabolite repression was isolated and purified from the yeast Pachysolen tannophilus. The enzyme phosphorylated D-fructose at a rate 1.5 times greater than that for D-glucose. The $K_{\mathrm{m}}$ values for D-glucose and D-fructose were 0.36 and $2.28 \mathrm{mM}$, respectively. Neither xylose reductase nor xylitol dehydrogenase were subject to catabolite repression in mutants defective in this enzyme.
\end{abstract}

\section{INTRODUCTION}

Two of the enzymes associated with xylose catabolism, aldose (xylose) reductase and xylitol dehydrogenase, have been purified from Pachysolen tannophilus and examined (Ditzelmuller et al., 1984a, b, 1985; Verduyn et al., 1985; Bolen et al., 1986; Morimoto et al., 1986, 1987). However, little is known about other enzymes in this yeast. We have recently demonstrated the existence of three hexose-phosphorylating enzymes in P. tannophilus; hexokinases A and B and a glucokinase specific for D-glucose (Wedlock et al., 1989; accompanying paper). In this paper, we report the isolation and partial purification of a hexokinase (ATP:D-hexose 6-phosphotransferase; EC 2.7.1.1), designated A, from a mutant which is defective in the glucokinase. The ahsence of the glucokinase, which co-elutes with hexokinase $\mathrm{A}$ in the wild-type strain of $P$. tannophilus, aids the isolation of the hexokinase without contamination by the glucokinase. The hexokinase PII enzyme of Saccharomyces cerevisiae has been implicated in catabolite repression (Kopetzki \& Entian, 1985; Hong \& Botstein, 1986) as has a hexokinase isolated from Schwanniomyces occidentalis (McCann et al., 1987). Xylose utilization by $P$. tannophilus is subject to hexose-sugar catabolite repression (Slininger et al., 1987; Bicho et al., 1988). The effect of the $P$. tannophilus hexokinase A on the activities of xylose reductase and xylitol dehydrogenase and on D-xylose utilization is described here.

\section{METHODS}

Yeast strains and growth conditions. The Pachysolen tannophilus strains used in enzyme analyses and sugar utilization experiments were P444-3 the wild-type strain, P510-5A defective in a glucokinase enzyme (glu1), P509$3 \mathrm{C}$ defective in hexokinase A ( $h x k 2)$ and P509-1 B defective in both hexokinase A and the glucokinase $(h x k 2 g l u 1)$. Strain P510-5A was also used in the purification of hexokinase A.

Cells were grown in 1 litre flasks containing $250 \mathrm{ml}$ of YEP-glucose [1\%,w/v, yeast extract (Difco), $2 \%, w / v$, peptone (Difco) and $2 \%, w / v, ~ D-g l u c o s e]$. The culture was incubated for $42 \mathrm{~h}$ at $30^{\circ} \mathrm{C}$ and 180 r.p.m. on a gyratory shaker. Cells grown for $48 \mathrm{~h}$ in YEP-glucose were used as the inoculum. For the measurement of xylose reductase and xylitol dehydrogenase activities, cells were grown for $16 \mathrm{~h}$ with either D-glucose, D-xylose, or D-glucose and Dxylose as carbon source.

Growth and sugar utilization were followed in YNB [0.67\% yeast nitrogen base (Difco), $2 \%$, w/v, sugar] liquid media. A $48 \mathrm{~h}$ YNB-xylose culture $(100 \mathrm{ml})$ was washed with deionized water and resuspended in water to an optical density of 34-36 units at $600 \mathrm{~nm}$ (Cecil linear readout UV spectrophotometer, model CE272). The final medium ( $100 \mathrm{ml} \mathrm{YNB}$-sugar in $250 \mathrm{ml}$ Erlenmeyer flasks) was inoculated with $0.5 \mathrm{ml}$ of the prepared inoculum and incubated at $30^{\circ} \mathrm{C}$ and 180 r.p.m. Growth was followed by measurement of optical density at $600 \mathrm{~nm}$ and sugars were analysed by HPLC with an refractive index detector, using a Bio-Rad HPX-87H column at $65^{\circ} \mathrm{C}$ and $5 \mathrm{mM}-\mathrm{H}_{2} \mathrm{SO}_{4}$ as the eluant. 
Purification of hexokinase $A$. The culture was washed twice with deionized water and resuspended in $10 \mathrm{ml}$ $100 \mathrm{mM}$-Tris $/ \mathrm{HCl}, \mathrm{pH} 7 \cdot 5$, containing the protease inhibitor PMSF (2 mM). Following two passages through a French pressure cell $(82.8 \mathrm{MPa})$, the debris was removed by centrifugation at $17500 \mathrm{~g}$ for $20 \mathrm{~min}$. The supernatant was used as a cell-free extract. Streptomycin sulphate was added slowly to the extract to a final concentration of $0.7 \mathrm{~g} \mathrm{ml}^{-1}$; the extract was left for $20 \mathrm{~min}$ and then centrifuged at $17500 \mathrm{~g}$ for $20 \mathrm{~min}$. The supernatant was desalted by passage through a Sephadex G-25 column and applied to a DEAE-cellulose (Whatman DE-52) column $(1.6 \times 20 \mathrm{~cm})$ equilibrated with $10 \mathrm{mM}$-potassium phosphate buffer, pH 7.5. The column was washed with four column volumes of buffer and the enzyme eluted with a $0-0.2 \mathrm{M}-\mathrm{NaCl}$ gradient. Fractions ( $5 \mathrm{ml})$ were collected and the hexokinase activity measured. Active fractions (typically six) exhibiting a fructose to glucose phosphorylation ratio of $1 \cdot 3 / 1.0$ were pooled and dialysed overnight against $5 \mathrm{~mm}$ potassium phosphate buffer, pH 6.5, containing $5 \mathrm{~mm}-\mathrm{MgCl}_{2}$. The enzyme was further purified by affinity chromatography on a column $(1.6 \times 18 \mathrm{~cm})$ of Cibacron FG-3A Blue Sepharose CL-6B. After washing with three column volumes of buffer, the enzyme was eluted with $10 \mathrm{~mm}$-Tris/ $\mathrm{HCl}$, pH 8.5, containing $15 \mathrm{mM}$-ATP. All purification steps were done at $4{ }^{\circ} \mathrm{C}$ and all buffers contained $1 \mathrm{mM}$-EDTA and $2 \mathrm{mM}$-2-mercaptoethanol. The purified enzyme was used for the determination of $K_{\mathrm{m}}$ values. Polyacrylamide disc gel electrophoresis on the purified enzyme was done according to the method of Gabriel (1971).

Enzyme assays. Cell-free extracts were prepared as described for the purification of hexokinase A, except cells were resuspended in $100 \mathrm{mM}-\mathrm{Tris} / \mathrm{HCl}, \mathrm{pH} 7 \cdot 5$, containing $0.2 \mathrm{mM}-\mathrm{PMSF}$, prior to breakage. Phosphorylation of D-glucose was measured by following the reduction of NADP+ at $340 \mathrm{~nm}$ (Joshi \& Jagannathan, 1966). For the measurement of D-fructose phosphorylation, D-fructose (15 mM) was used as the substrate and phosphoglucose isomerase (0.6 units) was added to the reaction mixture. D-Xylose reductase (EC 1.1.1.21) (Suzuki \& Onishi, 1973) and xylitol dehydrogenase (EC 1.1.1.9) (Touster \& Montesi, 1962) were assayed at a substrate concentration of $100 \mathrm{mM}$. All assays were done at $30^{\circ} \mathrm{C}$. Specific activity was expressed as $\mu \mathrm{mol}$ cofactor consumed $\min ^{-1}$ (mg protein) ${ }^{-1}$. Protein concentration was assayed by measurement of UV absorbance at $228.5 \mathrm{~nm}$ and $234.5 \mathrm{~nm}$ (Ehresmann, 1973) using bovine serum albumin as standard. All enzyme assays and protein concentration determinations were done in duplicate on two independently prepared cell-free extracts.

\section{RESULTS AND DISCUSSION}

The partial purification of hexokinase A from the glucokinase-less mutant of $P$. tannophilus is summarized in Table 1. The major glucose-phosphorylating activity in this strain was hexokinase A which constituted $90 \%$ of the overall activity; the remainder of the activity was due to the presence of hexokinase B. Fractionation of the two active hexokinases was achieved by chromatography on DEAE-cellulose (Wedlock et al., 1989), and with subsequent use of Blue Sepharose affinity chromatography, a purification of about 55 -fold was possible, with a yield of $10 \%$. When the enzyme preparation was run on a polyacrylamide disc gel, one major band and three or more minor bands were detected after staining with Coomassie Blue (Fig. 1). Stability of the enzyme was enhanced by inclusion of ATP in the elution buffer during the chromatography step on Blue Sepharose. Following elution of the enzyme, addition of glycerol to a final concentration of $10 \%(\mathrm{v} / \mathrm{v})$ also aided stability.

The $K_{\mathrm{m}}$ values for D-glucose and D-fructose were $0.36 \mathrm{mM}$ and $2.28 \mathrm{~mm}$, respectively as determined from a double reciprocal plot of initial reaction velocity, $V_{0}$, against substrate concentration, [S]. The maximum D-fructose/D-glucose phosphorylation $(\mathrm{F} / \mathrm{G})$ ratio was $1 \cdot 5 / 1 \cdot 0$, as predicted from the $V_{\text {fructose }} / V_{\text {glucose }}$ ratio. The $\mathrm{F} / \mathrm{G}$ ratio at the $15 \mathrm{~mm}$ substrate concentration used in the enzyme assays was $1 \cdot 3 / 1 \cdot 0$.

The partially purified enzyme from $P$. tannophilus appeared analogous to the hexokinase PII isoenzyme from Saccharomyces cerevisiae. The ratio of the rates of phosphorylation of D-fructose and D-glucose (Ramel et al., 1971; Colowick, 1973; Entian \& Mecke, 1982; Frohlich et al., 1984; Fernández et al., 1985) and the $K_{\mathrm{m}}$ values were similar to those reported for the PII isoenzyme in Saccharomyces cerevisiae (Entian et al., 1985).

The activities of the xylose pathway enzymes, xylose reductase and xylitol dehydrogenase, were measured in cell-free extracts of $P$. tannophilus prepared from cells grown on D-xylose, Dglucose or on a mixture of D-xylose and D-glucose. Activities of these enzymes in the wild-type strain, P444-3D, grown on D-xylose/D-glucose, were much lower than those in D-xylose-grown cells (Table 2). Only very low xylose reductase and xylitol dehydrogenase activities were found in D-glucose-grown cells. Both these enzymes in $P$. tannophilus have been previously shown to be 


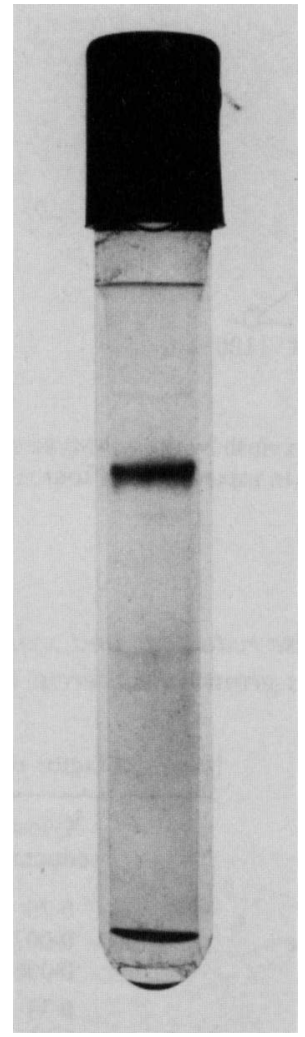

Fig. 1. Polyacrylamide gel electrophoresis of hexokinase A. The enzyme preparation ( $45 \mu \mathrm{g}$ protein) was electrophoresed at $32 \mathrm{~mA}$ for $1 \mathrm{~h}$ and stained with Coomassie Blue R-250 [20 mg ml-1 in methanol/acetic/acid water $(2: 1: 7$, by vol.)].

Table 1. Summary of partial purification of hexokinase $A$ from strain P510-5A

One unit (U) is $1 \mu \mathrm{mol} \mathrm{NADP}^{+}$reduced $\mathrm{min}^{-1}$ with $\mathrm{D}$-glucose as the substrate.

\begin{tabular}{|c|c|c|c|c|c|}
\hline Purification step & $\begin{array}{l}\text { Total } \\
\text { protein } \\
(\mathrm{mg})\end{array}$ & $\begin{array}{l}\text { Total } \\
\text { activity } \\
\text { (U) }\end{array}$ & $\begin{array}{c}\text { Specific } \\
\text { activity } \\
{\left[\mathrm{U}(\mathrm{mg} \text { protein })^{-1}\right]}\end{array}$ & $\begin{array}{l}\text { Yield } \\
(\%)\end{array}$ & $\begin{array}{l}\text { Purification } \\
\text { factor }\end{array}$ \\
\hline extract & $245 \cdot 0$ & 216 & 0.9 & 100 & 1.0 \\
\hline ycin sulphate & 162.0 & 191 & $1 \cdot 2$ & 88 & 1.4 \\
\hline exchange chromatography & $21 \cdot 0$ & 53 & 2.6 & 25 & $3 \cdot 0$ \\
\hline chromatography & 0.4 & 21 & $48 \cdot 4$ & 10 & 55.0 \\
\hline
\end{tabular}

induced by D-xylose (Maleszka et al., 1983; Bolen \& Detroy, 1985; Bicho et al., 1988) and repressed by D-glucose (Maleszka et al., 1983; Bicho et al., 1988). By comparison, the activities found in cells of the mutant P509-1B, defective in both hexokinase A and a glucokinase and grown on both D-glucose and D-xylose, were only slightly lower than those found in D-xylosegrown cells. This was true also of P509-3C, which has an active glucokinase but is defective in hexokinase A. Strain P510-5A, defective in the glucokinase but retaining an active hexokinase $A$, showed greatly reduced activities when grown on the D-glucose/D-xylose mixture compared to D-xylose. 

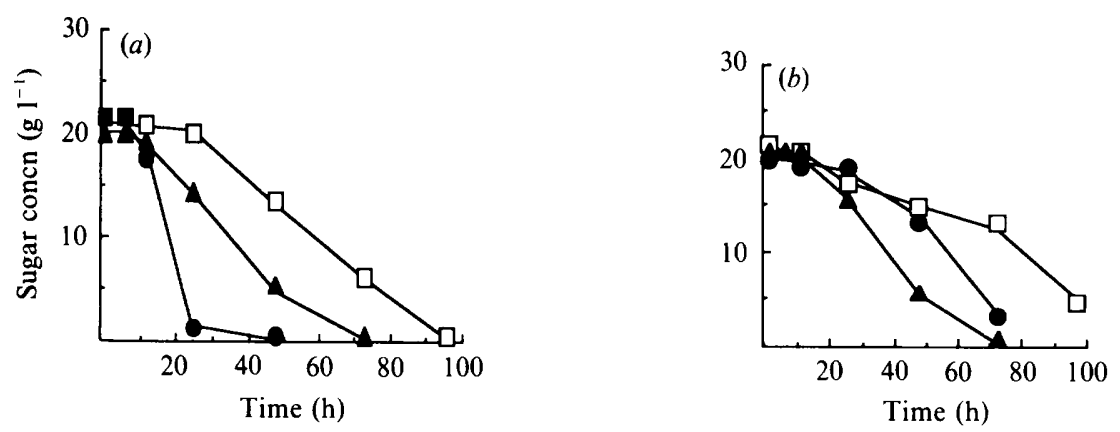

Fig. 2. Utilization of D-glucose and D-xylose by the wild-type strain P444-3D (a), and the mutant P5091B (b), in YNB media. D-Glucose (in mixed carbon source); $\square$, D-xylose (in mixed carbon source); $\Delta, \mathrm{D}-\mathrm{xylose}$ (as sole carbon source).

Table 2. Specific activities of xylose reductase and xylitol dehydrogenase in wild-type and mutant strains grown on different carbon sources

\begin{tabular}{|c|c|c|c|}
\hline \multirow{2}{*}{ Strain } & \multirow[b]{2}{*}{ Carbon source } & \multicolumn{2}{|c|}{$\begin{array}{l}\text { Specific activity } \\
{\left[\mu \mathrm{mols} \text { cofactor reduced or oxidized } \min ^{-1}(\mathrm{mg} \text { protein })^{-1}\right]}\end{array}$} \\
\hline & & $\begin{array}{l}\text { Xylose } \\
\text { reductase }\end{array}$ & $\begin{array}{c}\text { Xylitol } \\
\text { dehydrogenase }\end{array}$ \\
\hline P444-3D (wild-type) & $\begin{array}{l}\text { Xylose } \\
\text { Xylose + glucose } \\
\text { Glucose }\end{array}$ & $\begin{array}{l}0.26 \\
0.007 \\
0.006\end{array}$ & $\begin{array}{l}0 \cdot 24 \\
0 \cdot 028 \\
0 \cdot 006\end{array}$ \\
\hline P510-5A (glu1) & $\begin{array}{l}\text { Xylose } \\
\text { Xylose + glucose }\end{array}$ & $\begin{array}{l}0 \cdot 33 \\
0 \cdot 039\end{array}$ & $\begin{array}{l}0.29 \\
0.054\end{array}$ \\
\hline P509-3C (hxk2) & $\begin{array}{l}\text { Xylose } \\
\text { Xylose }+ \text { glucose }\end{array}$ & $\begin{array}{l}0 \cdot 34 \\
0 \cdot 21\end{array}$ & $\begin{array}{l}0 \cdot 28 \\
0 \cdot 20\end{array}$ \\
\hline P509-1B (hxk2 glu1) & $\begin{array}{l}\text { Xylose } \\
\text { Xylose + glucose }\end{array}$ & $\begin{array}{l}0 \cdot 34 \\
0 \cdot 23\end{array}$ & $\begin{array}{l}0 \cdot 28 \\
0 \cdot 25\end{array}$ \\
\hline
\end{tabular}

Characteristically, in media containing both D-glucose and D-xylose, the D-glucose was consumed preferentially by the wild-type strain (Fig. $2 a$ ). The utilization of D-xylose commenced when most of the D-glucose was depleted. This pattern has been reported previously (Detroy et al., 1982; Slininger et al., 1987; Bicho et al., 1988). A different pattern of sugar utilization was observed with strain P509-1B, which was able to co-utilize D-glucose and D-xylose (Fig. 2b). This strain can utilize D-glucose slowly, due to the presence of the hexokinase B, but D-glucose does not appear to repress the utilization of D-xylose to the same extent as with the wild-type strain.

From these results, the presence of hexokinase A appears to be necessary for catabolite repression of both xylose reductase and xylitol dehydrogenase. Thus, strains P509-3C and P5091B, which lack hexokinase A, showed only moderately lower xylose reductase and xylitol dehydrogenase activities when D-glucose was present in the medium. D-xylose utilization in strain P509-1B was no longer subject to repression by D-glucose. In Saccharomyces cerevisiae, there is evidence that hexokinase PII has a role in catabolite repression (Entian, 1980, 1981; Entian \& Mecke, 1982; Entian et al., 1984; Entian \& Frohlich, 1984; Kopetzki \& Entian, 1985; Hong \& Botstein, 1986). Recently, a hexose-phosphorylating enzyme in the yeast Schwanniomyces occidentalis has been associated with catabolite repression (McCann et al., 1987). From the present studies we conclude that hexokinase A from $P$. tannophilus, in addition to sharing similar kinetic properties to the Saccharomyces hexokinase, also plays a role in catabolite repression. By cloning and sequencing the structural gene for hexokinase A, further understanding of the molecular basis for catabolite repression in P. tannophilus may be acquired. 
This work was supported by NZ Forest Research Institute, contract no. 208, and NZ Energy Research and Development Committee, grant no. 3366.

\section{REFERENCES}

Bicho, P. A., Runnals, P. L., Cunningham, J. D. \& LEE, H. (1988). Induction of xylose reductase and xylitol dehydrogenase activities in Pachysolen tannophilus and Pichia stipitis on mixed sugars. Applied and Environmental Microbiology 54, 50-54.

Bolen, P. L. \& Detroy, R. W. (1985). Induction of NADPH-linked D-xylose reductase and NADlinked xylitol dehydrogenase activities in Pachysolen tannophilus by D-xylose, L-arabinose, or D-galactose. Biotechnology and Bioengineering 27, 302-307.

Bolen, P. L., Roth, K. A. \& Freer, S. N. (1986). Affinity purifications of aldose reductase and xylitol dehydrogenase from the xylose-fermenting yeast Pachysolen tannophilus. Applied and Environmental Microbiology 52, 660-664.

Colowick, S. P. (1973). The hexokinases. In The Enzymes, 3rd edn, vol. 9, pp. 1-48. Edited by P. D. Boyer. New York: Academic Press.

Detroy, R. W., Cunningham, R. L. \& Herman, A. I. (1982). Fermentation of wheat straw hemicelluloses to ethanol by Pachysolen tannophilus. Biotechnology and Bioengineering Symposium 12, 81-89.

Ditzelmuller, G., Kubicek, C. P., Wohrer, W. \& RoHR, M. (1984a). Xylose metabolism in Pachysolen tannophilus: purification and properties of xylose reductase. Canadian Journal of Microbiology 30, 1330-1336.

Ditzelmuller, G., Kubicek, C. P., Wohrer, W. \& RoHR, M. (1984b). Xylitol dehydrogenase from Pachysolen tannophilus. FEMS Microbiology Letters 25, 195-198.

Ditzelmuller, G., Kubicek-Pranz, E. M., Rohr, M. \& KUBICEK, C. P. (1985). NADPH-specific and NADH-specific xylose reduction is catalysed by two separate enzymes in Pachysolen tannophilus. Applied Microbiology and Biotechnology 22, 297-299.

EhresmanN, B., Imbault, P. \& Weil, J. H. (1973). Spectrophotometric determination of protein concentration in cell extracts containing tRNA's and rRNA's. Analytical Biochemistry 54, 454-463.

ENTIAN, K.-D. (1980). Genetic and biochemical evidence for hexokinase PII as a key enzyme involved in carbon catabolite repression in yeast. Molecular and General Genetics 178, 633-637.

ENTIAN, K.-D. (1981). A carbon catabolite repression mutant of Saccharomyces cerevisiae with elevated hexokinase activity: evidence for regulatory control of hexokinase PII synthesis. Molecular and General Genetics 184, 278-282.

ENTIAN, K.-D. \& FROHLICH K.-U. (1984). Saccharomyces cerevisiae mutants provide evidence of hexokinase PII as a bifunctional enzyme with catalytic and regulatory domains for triggering carbon catabolite repression. Journal of Bacteriology 158, 29-35.

ENTIAN, K.-D. \& MECKE, D. (1982). Genetic evidence for a role of hexokinase isozyme PII in carbon catabolite repression in Saccharomyces cerevisiae. Journal of Biological Chemistry 257, 870-874.

Entian, K.-D., Kopetzki, E., Frohlich, K.-U. \& MECKE, D. (1984). Cloning of hexokinase isoenzyme PI from Saccharomyces cerevisiae: PI transformants confirm the unique role of hexokinase isoenzyme PII for glucose repression in yeasts. Molecular and General Genetics 198, 50-54.

Entian, K.-D., Hilberg, F., Opitz, H. \& Mecke, D. (1985). Cloning of hexokinase structural genes from Saccharomyces cerevisiae mutants with regulatory mutations responsible for glucose repression. Molecular and Cellular Biology 5, 3035-3040.

Fernández, R., Herrero, P. \& Moreno, F. (1985). Inhibition and inactivation of glucose-phosphorylating enzymes from Saccharomyces cerevisiae by Dxylose. Journal of General Microbiology 131, 27052709.

Frohlich, K.-U., ENTIAN, K.-D. \& MECKE, D. (1984). Cloning and restriction analysis of the hexokinase PII gene of the yeast Saccharomyces cerevisiae. Molecular and General Genetics 194, 144-148.

GaBRIEL, O. (1971). Analytical disc gel electrophoresis. Methods in Enzymology 22, 565-578.

HoNG, M. A. \& BotsteIN, D. (1986). Effects of null mutations in the hexokinase genes of Saccharomyces cerevisiae on catabolite repression. Molecular and Cellular Biology 6, 4046-4052.

Joshi, M. D. \& Jagannathan, V. (1966). Hexokinase I. Brain. Methods in Enzymology 9, 371-376.

KopetzKI, E. \& ENTIAN, K.-D. (1985). Glucose repression and hexokinase isoenzymes in yeast. Isolation and characterisation of a modified hexokinase PII isoenzyme. European Journal of Biochemistry 146, 657-662.

MaleszKa, R., Neirinck, L. G., James, A. P., RutTEN, H. \& SCHNEIDER, H. (1983). Xylitol dehydrogenase mutants of Pachysolen tannophilus and the role of xylitol in D-xylose catabolism. FEMS Microbiology Letters 17, 227-229.

McCann, A. K., Hilberg, F., Kenworthy, P. \& BARnETT, J. A. (1987). An unusual hexose-ATPkinase with two catabolite sites and a role in carbon catabolite repression in the yeast Schwanniomyces occidentalis. Journal of General Microbiology 133, 381-389.

Morimoto, S., Matsuo, M., Azuma, K. \& Sinskey, A. J. (1986). Purification and properties of Dxylulose reductase from Pachysolen tannophilus. Journal of Fermentation Technology 64, 219-225.

Morimoto, S., Takahiko, T., Azuma, K., Oshima, T. \& SinSKEY, A. J. (1987). Purification and properties of aldose reductase from Pachysolen tannophilus. Journal of Fermentation Technology 65, 17-21.

Ramel, A. H., Rustrum, Y. M., Jones, J. G. \& BARNARD, E. A. (1971). Yeast hexokinase. IV. Multiple forms of hexokinase in the yeast cell. Biochemistry 10, 3499-3508.

Slininger, P. J., Bolen, P. L. \& Kurthman, C. P. (1987). Pachysolen tannophilus: properties and process considerations for ethanol production from Dxylose. Enzyme and Microbial Technology 9, 5-15.

SuzUKI, T. \& ONISHI, H. (1973). Oxidation and reduction of D-xylose by cell-free extract of Pichia quercuum. Applied Microbiology 25, 850-852.

TOUSTER, O. \& MoNTESI, G. (1962). Xylitol dehydro- 
genase (DPN and TPN). Methods in Enzymology 5, WeDlock, D. N., JAMEs, A. P. \& THORNTON, R. J. $317-322$.

Verduyn, C., Jzn, J. F., van Dijken, J. P. \& (1989). Glucose-negative mutants of Pachysolen SCHEFFERS, W. A. (1985). Multiple forms of xylose reductase in Pachysolen tannophilus CBS4044. FEMS tannophilus. Journal of General Microbiology 135, Microbiology Letters 30, 313-317. 